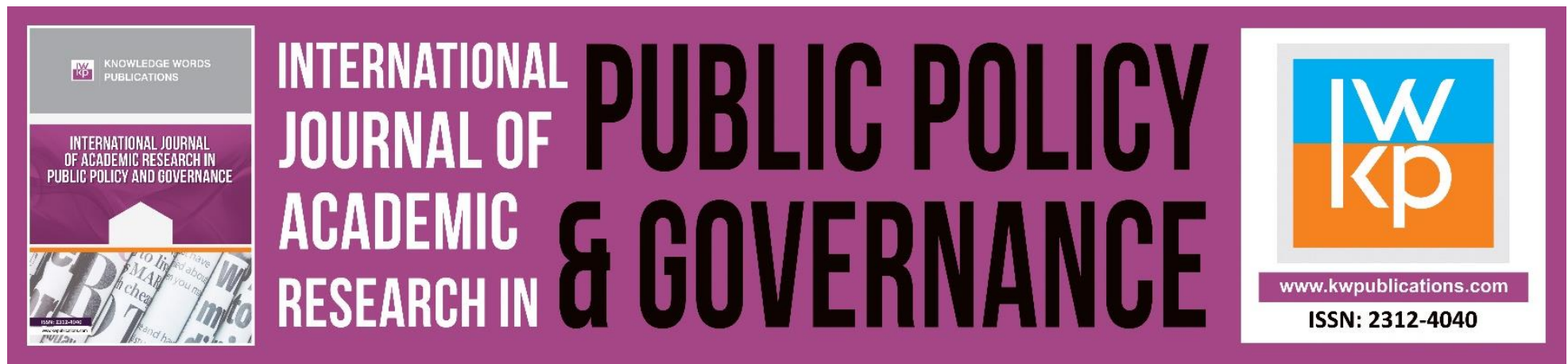

\title{
Human Trafficking: History and the Recent Development
}

\author{
Usman Mika'il Usman
}

To Link this Article: http://dx.doi.org/10.46884/IJARPPG/v7-i1/7004

DOI:10.46884/IJARPPG/v7-i1/7004

Received: 08 January 2020, Revised: 13 February 2020, Accepted: 16 March 2020

Published Online: 28 April 2020

In-Text Citation: (Usman, 2020)

To Cite this Article: Usman, U. M. (2020). Human Trafficking: History and the Recent Development. International Journal of Academic Research in Public Policy and Governace, 7(1), 1-10.

Copyright: (C) 2020 The Author(s)

Published by Knowledge Words Publications (www.kwpublications.com)

This article is published under the Creative Commons Attribution (CC BY 4.0) license. Anyone may reproduce, distribute, translate and create derivative works of this article (for both commercial and non-commercial purposes), subject to full attribution to the original publication and authors. The full terms of this license may be seen

at: http://creativecommons.org/licences/by/4.0/legalcode

Vol. 7, No. 1, 2020, Pg. 1 - 10

http://kwpublications.com/index.php/pages/detail/IJARPPG

JOURNAL HOMEPAGE

Full Terms \& Conditions of access and use can be found at https://kwpublications.com/pages/detail/publication-ethics 


\title{
Human Trafficking: History and the Recent Development
}

\author{
Usman Mika'il Usman \\ Ph.D. Candidate at the Department of Development Studies, Faculty of Economics and \\ Administration, University of Malaya, 50603 Kuala Lumpur, Malaysia. \\ Email: umu9933@gmail.com
}

\begin{abstract}
Human trafficking is a clandestine, complex and global phenomenon involving almost all countries. History has it that the emergence and appearance of trafficking in persons are believed to have emanated from the slave trade era. However, the recent development in terms of defining the menace proved a difficulty that demonstrates continued human exploitation. This study is nearly the first attempt to critically look into the history of the anti-trafficking conventions as well as the current stands, which shows limited success in combating modern-day slavery. The investigation is a content analysis that uses scholarly published journals on human trafficking that identified the history and the current happenings within the anti-trafficking pacts or resolutions. The research explores how the human trafficking definition keeps changing over several decades to the present situation. The findings reveal contrasting and nuanced similar views and the research proffer the way forward.
\end{abstract}

\section{Introduction}

Historically, trafficking in humans is hidden, dirty and dangerous exploitation that has become a global crime. Human trafficking particularly dealing with young women for sex trafficking has spread to all the continents of the world. The menace is now a serious issue of the unlawful international economy for the criminal networks. The development in defining human trafficking and happenings over the recent years is said by scholars to have generated ambiguity, clarity, confusion and varying views because of the basic reasons within the history of the anti-trafficking legislations. This study found that presently human trafficking flourishes in this globalized and interconnected world. In light of the fact that the legal means to checkmate the menace lies with states, while the chunk of the criminals is transnational. The network of criminals has connections not only in their countries but as well as in transiting and destination nations. Most importantly, anti-trafficking conventions have largely described the fundamental procedures for combating international or human trafficking. Especially trafficking for the purpose of female prostitution, which is severe, and the international community said that trafficking in persons was a violation of human rights (United Nations Office on Drugs and Crime, 2000). The conventions have largely declared that enslavement of women, men and children is an infringement of their fundamental rights. Though, despite the fact that the majority 
INTERNATIONAL JOURNAL OF ACADEMIC RESEARCH IN PUBLIC POLICY AND GOVERNANCE Vol. 7, No. 1, 2020, E-ISSN: 2312-4040 ๔ 2020 KWP

of the global countries have signed the anti-trafficking protocol, exploitation is ongoing at an alarming rate (International Labour Organisation, 2018). For these reasons, this research is practically the first attempt to look into the historical and recent development of the anti-trafficking conventions. That is to say, the investigation is distinct in trying to explain what is needed to reduce or eliminate the various stands within the human trafficking definitional approach.

\section{Literature}

Venson and Pedro (2013) in their historical submission said human trafficking was initially introduced in the nineteenth century and resurfaced with full force towards the end of the twentieth century. According to the authors, that was the time when prostitution was first mentioned and brought to the limelight to the global discourse on human trafficking. Enrile (2017) work opines that human trafficking emanates or is inseparable from the history of human slavery. That means, it is the legacy of the colonialists and the imperialist nations. As such, human trafficking is the end product of agricultural slavery, which saw the birth of the scourge and it lasted until the end of the nineteen century. Similarly, Chapdelaine (2015) cited the historical development of human trafficking is traced to the transatlantic dealing in slavery, servitude and slave trade. Whereas Winterdyk (2019) book entitled "explaining human trafficking: modern day slavery" is of the view that human trafficking is a complex, diverse and multifaceted global phenomenon without states agreeing on a single definition. To him trafficking in person is at the moment modern-day slavery due to forceful and deceitful sexual exploitation in victims. Okech, Choi, Elkins, and Burns (2018) confirm that historically and in recent times children and women are the hard-hit victims of human trafficking globally. However, the recent development shows females are exploited largely as domestic house help, construction work, agricultural sector, manufacturing and in sexual industries mainly for economic gains (Bonilla \& Mo, 2019). Undoubtedly, this constitutes a great violation of the rights of persons and abuse of the fundamental freedom of humans. Presently, the lack of a universally agreed global definition is what has given transnational criminals persistence human trafficking exploitation.

\section{Methodology}

The main or critical challenge in conducting a human trafficking study is the absence of reliable data. One such explanation has to do with the fact that it is a secret, complex and the absence of agreed definition. Hence, the actual persons exploited globally are not known. As a result of this conundrum, this article utilises content analysis on human trafficking via historical publication that focuses on what the menace is and how the recent development continues. Articles, journals, are collected through a thorough search on official government sites within Nigeria, and globally. (Vaismoradi \& Snelgrove, 2019). While many journals did not touch on historical and recent development. Yet, this article has offered a thick, extensive and detailed explanation with regards to the current anti-human trafficking history. The study themes emerged deductively from the critical and deeper understanding of the works of literature reviewed. Fortunately, this research answers the question and illustrate how human trafficking pacts or conventions will address the modern-day slavery successfully.

\section{Findings}

\section{Human Trafficking: History and Recent Development}

Several scholars and researchers insist that the first indication of human trafficking on the planet showed up a couple of hundred years, as far back as the trans-Atlantic slavery or slave trade (Bravo, 
INTERNATIONAL JOURNAL OF ACADEMIC RESEARCH IN PUBLIC POLICY AND GOVERNANCE Vol. 7, No. 1, 2020, E-ISSN: 2312-4040 ๔ 2020 KWP

2007; Davidson, 2017; Munck, 2010). Other scholars view trafficking as exploitation, express that the starting points of the contemporary trafficking in human are historically traced to the late nineteenth century (Doezema, 2002; Eliot, 2019; Newman, 2017). Whereas, international trafficking in young women for sexual exploitation gained momentum in the late nineteenth century. While slavery is centered around exploitation of labour, young women were trafficked out of Africa to Europe to fill in as mine workers', wives or as prostitutes. At the same time, numerous African young girls were trafficked to Europe and a lot of them were oppressed as prostitutes in various French ports (BryantDavis, \& Tummala-Narra, 2017; Martens, Pieczkowski \& Vuuren-Smyth, 2003).

However, England was the primary or leading state behind the stoppage of trans-Atlantic slavery. Under the banner and concern for humans, the English parliament prohibited the slave trade with the slave Act in 1807 which became effective first of January 1808 (Lee, 2013). England, utilising its naval power, diplomats and armies, continued to nullify slavery and in 1833 through her colonies, territories authorise the abolition of the slavery policy throughout the globe (Andreas \& Nadelmann, 2008). Whereas in Asia, the Middle East and the Americas, slave trade proceeded into the mid of the nineteenth century, in spite of English pressure to abolish it. In America, it was in 1865 with the enactment of the Thirteenth Amendment prior to her civil war when slavery was abolished. Though more countries and individuals saw the slave trade as ethically wrong. That means, slaveholders lost economically and felt the socioeconomic impact, and the dealings in humans as slave vanished. The slave trade apparently ended in the United States of America (Davidson, 2017; Alzgool, 2019); Muhammad, Saoula, Issa \& Ahmed, 2019).

In this case, the mid of the nineteenth century, the development around the white slavery became widely known as the abolitionist stands, started in Britain and other western European nations. Also, the United States was against human trafficking (Lusk \& Lucas, 2009). The issue got media attention, various associations were set up to battle human trafficking including prostitution. International and national policies were enacted to end slavery. In response to the white slave trade, the League of Nations (now the United Nations) drafted in 1902 the forerunner international abolitionist agreement against slavery in Paris. It was ratified two years after by sixteen countries and later endorsed by about 100 governments (Irwin, 2017; Khalid, Islam \& Ahmed, 2019). The international convention for the repression of the persons for slavery 1904 dealt with deceitful and coercive recruitment especially white women for prostitution. This agreement characterised trafficking for prostitution as an ethical issue identified with slavery and was planned to address the internalisation of European women into different parts of pre-revolutionary colonies for prostitution. The convention accommodated the states to allude victims to private or public charitable organisations, or for the people to offer them essential security prior to their repatriation (Allain, 2018; Wharton, 2009). Despite the fact that the white slave accord aimed to stifle white slavery, this accord just required states that are party to it to gather information on how do women cross transnational borders.

The 1904 agreement demonstrated to a great extent its insufficiency to combat human trafficking. Its scope was widened in the year 1910 to incorporate the trafficking of girls and young women within and across countries' borders. Then again, in 1921 the trafficking of young boys was additionally consolidated into the agreement. That is the international convention for the suppression of traffic in women and children. This treaty attended to human trafficking issues (Lobasz, 2009; Wharton, 2009). However, considering its main purposes, such as seen prostitution as an issue of national jurisdiction. Along these lines restricting the extent of the convention to transportation and recruitment within or and nationally. In this case, the agreement extended its limitation, thereby 
INTERNATIONAL JOURNAL OF ACADEMIC RESEARCH IN PUBLIC POLICY AND GOVERNANCE Vol. 7, No. 1, 2020, E-ISSN: 2312-4040 @ 2020 KWP

providing protective measures that were not given by the past instruments. For instance, the white slave Act was said to incorporate the non-white children and women. The convention is said to be weak, as no meaning of trafficking or traffic was clearly stated (Chong, 2014; Chuang, 1998). Due to this puzzle, another global instrument was embraced to address human trafficking. The antitrafficking convention is said to be encompassing. This is because it calls human trafficking as the servitude, slavery, forced labour, and similar practices. Also, the anti-trafficking pact or agreement of 1926 is thought to establish the boundary of human trafficking definition and the anti-trafficking practices. It characterised slave trade and slavery as activities of either selling, buying or exchange and generally to trade in humans is prohibited. The definition is pointed to have concentrated on components of trafficking, such as compulsion and lack of liberty (Allain, \& Bales, 2012; Morrison \& Crosland, 2001 cited in Jakobsson \& Kotsadam, 2013).

However, a succeeding Act is the 1933 convention, known as the international convention for the suppression of the traffic in women. This agreement banned all acts of recruitment related to human trafficking, which includes prostitution. It additionally stated that consent by a trafficked woman did not mean protection to the menace of universal trafficking (Farrior, 1997). In the same vein, the four mentioned global instruments were consolidated by the United Nations to create a robust convention for the suppression of the traffic in persons, and of the exploitation of the prostitution of others in the year 1950. It is subsequently viewed as the primary merged trafficking in person convention internationally. Nevertheless, it is cited to have focused only on prostitution (Chuang, 1998). This covenant constrained its scope to force trafficking for prostitution across borders, which is prohibited or criminalised (even with or without the consent and to the parties concerned). The motivation behind the covenant was to penalise any individual who acquires and traffic women. Though, other identifiers or similar practices related to prostitution, regardless of the trafficked victims' consent or age (Amiel, 2006). Despite the fact that trafficking for prostitution was viewed as a universal issue for the very first time, its prevention and punishment were handled within the country's jurisdiction. Moreover, the convention needed implementation components given the noncompulsory nature of its arrangements. It did not have an obligatory reporting mechanism or an authoritative order for a global community to supervise its implementation and was not approved or endorsed by the majority of the states (Coomaraswamy, 1999 cited in Gonzalez, 2002). Again, the 1950 accord, the term trafficking in person was defined by the United Nations and it is said to be the first definition of the concept. However, the term was held solely for the sexual exploitation of children and women for prostitution.

Then again, in the 1956 supplementary convention was enacted to abolish slavery, the slave trade, and practices similar to slavery. This instrument broadened the meaning of slavery and slavery-like practices by proscribing child servitude, debt bondage, servile marriage, and serfdom. The 1956 supplementary convention concentrated to end the slave trade and similar practices (Wong, 2011). The convention never in any way define the phrase 'right of ownership', which made it possible for the correlation between human trafficking and slavery. Thus, making the interpretation of these terms to continue to generate controversy and ambiguity.

Towards the end of the 1980s and in the early 1990s a fresh enthusiasm for the issue of trafficking in humans resurfaced internationally. This was impacted by advancements in regard to migration flow, prostitution, sex tourism, HIV/AIDS endemic and the movement of the feminist (Doezema, 1999). In Southeast Asia, sex tourism and trafficking of girls and young women from poor nations to North America and Western Europe raised worry amongst the public and policymakers for the fact that no new pact was embraced. Though the 1950 convention was still active, pressure led to about 70 
countries ratified the convention by the year 1996. Besides, it was said to be obsolete and deficiently ineffective to end either labor exploitation or prostitution in women. The Convention's approach was seen by numerous as insufficient as its target was not to end prostitution in practical terms. Nonetheless, the abolitionist movement demanded that there is a connection between prostitution and human trafficking. They contended that like trafficking in person, prostitution could scarcely be consensual. And that human trafficking, as well as prostitution, involves largely women. The abolitionist mentioned that the 1950 convention was just not legitimately upheld. Therefore, the capacity of the convention coupled with persistence and recent acts of traffic was a vital issue to be looked upon as stated by them (abolitionist) and other pressure groups. These forces prompted the debate of trafficking in persons especially that of children and women re-emerged on the plans of the United Nations General Assembly in the 1990s. At this juncture, at the global level (UN), requests were evolving for a far-reaching and precise definition involving each type of trafficking (Chang \& Kim 2007). As needs arise significantly, in November 2000 the UN General assembly embraced the Palermo protocol. On this note, recent development with regards to the Palermo human trafficking definition shows various distinct schools of thought. Firstly, Anderson and Julio (2004) and Caudwell (2018) and Duong (2019) and Mordeson, Mathew and Malik (2018) postulated that the recent human trafficking involves a variety of activities that could mean various outcome. These proponents refer to trafficking as a process of control, recruitment, and transportation that could be organised in different ways and involve various persons and outcomes. According to this school of thought, there is no uniform or agreed definition of the term 'sexual exploitation' or 'abuse' but the scholars' view is that the scourge depends on the kind of trafficking or the magnitude of the victim's exploitation. Another school of thought involves, Doezema (2002) and Jordan (2002) and Snow and Smith and Radatz (2019) and Papanicolaou and Boukli (2019). These writers see the meaning of human trafficking as a 'deliberate ambiguity' such that, the protocol allowed governments to define human trafficking as they wish. In their submission, the current stands by different governments are exactly what the anti-trafficking definition portrays. That is to say, some governments legalise or support human trafficking. Whereas the majority of the world countries have criminalised and do not in any way support human trafficking. Most importantly, the third scholarly world view include El Khoury (2020) and Farrell and Bouche and Wolfe (2019) and Ikeora (2017) and Lobasz (2019) they postulated that the millennium year is significant to anti-human trafficking definition, as governments are to ensure necessary measures to protect victims, prevent trafficking and prosecute traffickers to end the scourge. These scholars pointed to the call of action by the anti-trafficking document. According to this school of thought, despite the debate that surrounds human trafficking, the Palermo protocol has clearly stated the act, means, and purpose of human trafficking definition. The scholarly opinion is that trafficking in persons well established and the boundary of the convention made known.

\section{Conclusion and Recommendations}

History has it that the emergence and appearance of trafficking in persons are believed to have emanated from the slave trade era. The pacts, agreements, and conventions that define human trafficking and the developments over the recent years are said to have generated ambiguity, clarity, confusion and varying scholarly views because of the antecedents within the history of the antitrafficking legislations. However, the recent development in the fight against the menace proved a difficulty that demonstrates continued human exploitation due to the definitional conundrum. On this note, scholars found human trafficking to involve a variety of activities that could mean various outcomes. Accordingly, there is no uniform or agreed definition of the term 'sexual exploitation' or 'abuse' but the scholars' view is that the scourge depends on the kind of trafficking or the magnitude 
of the victim's exploitation. Others see the meaning of human trafficking as a deliberate ambiguity such that, the protocol allowed governments to define human trafficking as they wish. That is to say, some governments legalise or support human trafficking. Whereas the majority of the world countries have criminalised and do not in any way support human trafficking. Most importantly, the major scholarly world view sees the recent development as significant to the anti-human trafficking definition. This is because governments are to ensure necessary measures to protect victims, prevent trafficking and prosecute traffickers to end the scourge. That means the Palermo protocol has clearly stated the act, means, and purpose of what constitutes the human trafficking definition.

This investigation suggests strengthening the existing human trafficking legislation. That is to say, the Palermo protocol should focus on addressing the victims' rights, needs and demands as enshrined in the convention. Such action will be a key measure in a drastic reduction or elimination of the scourge. This is a practical result. Instead of initiating a new convention, there is a lack of implementation of the Palermo policy by many states and is the main reason why exploitation continues, and victims are expanding globally. Governments need to consider the 'special attention' clause as envisaged by the protocol. This study calls on states to put activities or programs that will translate policy into actual practice or action. This will only happen when implementation is done with concern commitment and resources. Finally, convention, protocol, and the definitional gap will end as well as tame the fight of human trafficking and defeat human traffickers.

\section{References}

Abadinsky, H. (2003) Organized Crime, 7th edition. Belmont, CA: Wadsworth.

Allain, J. (2018). Genealogies of human trafficking and slavery. Routledge Handbook of Human Trafficking. Routledge, New York.

Allain, J., \& Bales, K. (2012). Slavery and its definition. Global Dialogue, 14(2), 6-14.

Alzgool, M. (2019). Nexus between Green HRM and Green Management towards Fostering Green Values. Management Science Letters, 9(12), 2073-2082.

Amiel, A. (2006). Integrating a human rights perspective into the European approach to combating the trafficking of women for sexual exploitation. Human Rights, 12, 5.

Anderson, B., \& Davidson, J. O. C. (2004). Trafficking-a Demand Led Problem? Save the Children Sweden.

Andreas, P., \& Nadelmann, E. A. (2008). Policing the globe: Criminalization and crime control in international relations. Oxford University Press.

Bonilla, T., \& Mo, C. H. (2019). The evolution of human trafficking messaging in the United States and its effect on public opinion. Journal of Public Policy, 39(2), 201-234.

Bravo, K. E. (2007). Exploring the analogy between modern trafficking in humans and the transAtlantic slave trade, International Law Journal, 25(2), 207-209.

Bryant-Davis, T., \& Tummala-Narra, P. (2017). Cultural oppression and human trafficking: Exploring the role of racism and ethnic bias. Women \& Therapy, 40(1-2), 152-169.

Caudwell, J. (2018). Sporting events, the trafficking of women for sexual exploitation and human rights The Palgrave Handbook of Feminism and Sport, Leisure and Physical Education (pp. 537556): Springer.

Chang, G., \& Kim, K. (2007). Reconceptualizing approaches to human trafficking: New directions and perspectives from the field (s). Stanford Journal of Civil Rights \& Civil Liberties, 3(2), 317-344.

Chapdelaine, R. P. (2015). Linking History to Practice: Mapping the History of Nigeria as a Tool to Combat Human Trafficking Today. The Social Practice of Human Rights, 3, 1-2. 
INTERNATIONAL JOURNAL OF ACADEMIC RESEARCH IN PUBLIC POLICY AND GOVERNANCE

Vol. 7, No. 1, 2020, E-ISSN: 2312-4040 ๔ 2020 KWP

Chong, N. G. (2014). Human trafficking and sex industry: Does ethnicity and race matter? Journal of Intercultural Studies, 35(2), 196-213.

Chuang, J. (1998). Redirecting the debate over trafficking in women: Definitions, paradigms, and contexts. Human Rights Journal, 11, 65.

Davidson, J. O. C. (2017). The Presence of the Past: Lessons of history for anti-trafficking work. AntiTrafficking Review, (9). 1-12.

Doezema, J. (1999). Loose women or lost women? The re-emergence of the myth of white slavery in contemporary discourses of trafficking in women. Gender issues, 18(1), 23-50.

Doezema, J. (2002). Who gets to choose? Coercion, consent, and the UN Trafficking Protocol. Gender \& Development, 10(1), 20-27.

Dottridge, M. (2017). Trafficked and Exploited: The Urgent Need for Coherence in International Law. Revisiting the Law and Governance of Trafficking, Forced Labour and Modern Slavery, 59.

Duong, K. A. (2019). Human Trafficking and Migration: Examining the Issues from Gender and Policy Perspectives. The Palgrave

El Khoury, J. (2020). Combatting Human Trafficking in Lebanon: Prosecution, Protection, and Prevention. The Palgrave International Handbook of Human Trafficking, 1205-1217.

Eliot, L. B. (2019). We don't recognize your freedom: Slavery, imperialism, and statelessness in the mid-nineteenth century Atlantic World. Atlantic Studies, 16(4), 482-501.

Enrile, A. (2017). Ending Human Trafficking and Modern-day Slavery: Freedom's Journey: SAGE Publications.

Farrell, A., Bouche, V., \& Wolfe, D. (2019). Assessing the Impact of State Human Trafficking Legislation on Criminal Justice System Outcomes. Law \& Policy, 41(2), 174-197.

Farrior, S. (1997). The international law on trafficking in women and children for prostitution: Making it live up to its potential. Human Rights Journal, 10, 213.

Gallagher, A. (2001). Human rights and the new UN protocols on trafficking and migrant smuggling: A preliminary analysis. Hum. Rts. Q., 23, 975.

Gallagher, A. T. (2017). The International Legal Definition of Trafficking in Persons: Scope and Application. Revisiting the Law and Governance of Trafficking, Forced Labor and Modern Slavery, 83.

Gonzalez, W. M. (2002). Human trafficking: Criminalization of victims in the sex industry. Women's LJ, 11, 19.

International Labour Organisation. (2017). Forced labour, modern slavery, and human trafficking. Retrieved from https://www.ilo.org/global/topics/forced-labour/lang--en/index.htm.

Irwin, N. (2017). Police officer understandings of human trafficking and awareness of anti-trafficking measures. Policing: An International Journal of Police Strategies \& Management, 40(2), 291305.

Jakobsson, N., \& Kotsadam, A. (2013). The law and economics of international sex slavery: prostitution laws and trafficking for sexual exploitation. European journal of law and economics, 35(1), 87-107.

Kaplan, D., and Dubro, A. (2003) Yakuza: Japan's Criminal Underworld. Berkeley: University of California Press.

Khalid, N., Islam, D. M. Z., \& Ahmed, M. R. M. (2019). Sentrepreneurial Training and Organizational Performance: Implications for Future. Humanities \& Social Sciences Reviews, 7(2), 590-593.

Lee, M. (2013). Introduction: Understanding human trafficking. London: Willan. 
INTERNATIONAL JOURNAL OF ACADEMIC RESEARCH IN PUBLIC POLICY AND GOVERNANCE

Vol. 7, No. 1, 2020, E-ISSN: 2312-4040 ๔ 2020 KWP

Lindstrom, N. (2004) 'Regional Sex Trafficking in the Balkans: Transnational Networks in an Enlarged Europe', Problems of Post-Communism, 53 (4).

Lintner, B. (2003) Blood Brothers: The Criminal Underworld of Asia. New York: Palgrave MacMillan.

Lobasz, J. K. (2009). Beyond border security: Feminist approaches to human trafficking. Security Studies, 18(2), 319-344.

Lobasz, J. K. (2019). The Trafficking Victims Protection Act of 2000 Constructing Human Trafficking (pp. 69-113): Springer.

Lusk, M., \& Lucas, F. (2009). The challenge of human trafficking and contemporary slavery. Journal of comparative social welfare, 25(1), 49-57.

McAdam, M. (2018). The International Legal Framework on Human Trafficking: Contemporary Understandings and Continuing Confusions. The SAGE Handbook of Human Trafficking and Modern-Day Slavery, 18

Mordeson, J. N., Mathew, S., \& Malik, D. S. (2018). Human trafficking: Source, transit, destination designations Fuzzy Graph Theory with Applications to Human Trafficking (pp. 181-208): Springer.

Muhammad, K., Saoula, O., Issa, M., \& Ahmed, U. (2019). Contract Management and Performance Characteristics: An Empirical and Managerial Implication for Indonesia. Management Science Letters, 9(8), 1289-1298.

Munck, R. (2010). Slavery: exception or rule? In Human Trafficking in Europe (pp. 17-29). Palgrave Macmillan, London

Munro-Kramer, M., Beck, D., Choi, K., Singer, R., Gebhard, A., \& Carr, B. (2019). Human Trafficking Victim's Service Needs and Outcomes: An Analysis of Clinical Law Data. Journal of Human Trafficking, 1-14.

Newman, B. N. (2017). Historical perspective: Slavery over the centuries Human Trafficking. London: Routledge.

Okech, D., Choi, Y. J., Elkins, J., \& Burns, A. C. (2018). Seventeen years of human trafficking research in social work: A review of the literature. Journal of evidence-informed social work, 15(2), 103122.

Pearson, E. (2001). Human rights and trafficking in persons: a handbook: Global Alliance Against Traffic in Women.

Saunders, P. (2005). Traffic violations: Determining the meaning of violence in sexual trafficking versus sex work. Journal of Interpersonal Violence, 20(3), 343-360.

Smucker, P. (2004) 'Sahara Town Booms with People Smuggling', International Herald Tribune, 25 October 2004,

Snow, N. M., Smith, M., \& Radatz, D. L. (2019). Human Trafficking and Prostitution. The Encyclopedia of Women and Crime, 1-3.

United Nations Convention against transnational organized crime. http:// www.unodc.org/ documents/treaties/UNTOC/Publications/.

United Nations Office on Drugs and Crime. (2000). Protocol to prevent, suppress and punish trafficking in persons, especially women and children, supplementing the United Nations Convention against Transnational Organised Crime. Retrieved from http://www.unodc.org/unodc/en/organized-crime/intro/UNTOC.html.

Vaismoradi, M., \& Snelgrove, S. (2019). Theme in qualitative content analysis and thematic analysis. Qualitative Social Research, 20(3), 
Venson, A. M., \& Pedro, J. M. (2013). Human trafficking: a historical approach to the concept. Revista Brasileira De Historia, 33(65), 61-83.

Wharton, R. L. (2009). A new paradigm for human trafficking: Shifting the focus from prostitution to exploitation in the trafficking victims protection act. Wm. \& Mary J. Women \& L., 16, 753.

Winterdyk, J. A. (2019) Explaining Human Trafficking: Modern Day Slavery. In: Winterdyk J., Jones J. (eds) The Palgrave International Handbook of Human Trafficking. Palgrave Macmillan, Cham.

Wong, W. H. (2011). Is trafficking slavery? Anti-slavery international in the twenty-first century. Human Rights Review, 12(3), 315-328. 